\title{
Sveriges relationer med Ryssland: kontinuitet och förändring historiskt och idag
}

\author{
Martin Kragh $\star$ \\ $\mathrm{PhD}$, programchef och seniorforskare, Utrikespolitiska institutet, Stockholm
}

\begin{abstract}
Swedish-Russian Relations: Continuity and Change Historically and Today Relations between Sweden and Russia have historically been characterized by continuity and stability, despite occasional periods of friction. On the one hand, Sweden and Russia have a more active bilateral agenda than what is usually recognized, primarily in the areas of trade, investments and cultural and educational exchanges. On the other hand, there are several issues - like the Ukraine conflict, the EU Eastern Partnership, Swedish NATO cooperation and the security situation in the Baltic Sea area - involving competing claims and interests between Sweden and Russia. Further, Swedish foreign policy since the 1990s has been framed within a multilateral context, and that has a bearing on Swedish-Russian relations as well. This situation is likely to continue, unless dramatic changes occur in the political relations between Russia and the Western powers.
\end{abstract}

Keywords: Russia, Sweden, trade, investments, history, relations

Inom gruppen europeiska småstater har de nordiska länderna historiskt betraktat tillhört de mest lyckosamma. Det mest lyckosamma av de nordiska länderna har i sin tur varit Sverige. Sedan 1800-talets sista kvartal har de nordiska länderna med få avbrott upplevt stark ekonomisk utveckling, politisk stabilitet och demokratisering. Sverige, i motsats till grannländerna Danmark, Norge och Finland, har sedan 1809 därtill varit förskonat från väpnad konflikt på eget territorium. Sveriges position bland de nordiska staterna de senaste två århundradena har också format landets relationer till Ryssland - den enda av Östersjöns strandstater som utgjort en nästintill konstant svensk säkerhetspolitisk utmaning trots gemensamma intressen inom vissa områden.

För att förstå de svensk-ryska relationerna är distinktionen mellan stormakt och småstat central. Ett grundantagande i denna artikel är att Ryssland, enkelt uttryckt, spelar en asymmetriskt större roll för svensk utrikespolitik än tvärtom - något som historiskt sett varit sant $\mathrm{i}$ såväl freds- som krigstid. Detta förhållande gäller också för småstater generellt (Fox 1959; Handel 1981; Labs 1992; Ringsmose 2009).

\footnotetext{
^Kontaktinformasjon: Martin Kragh, e-post: martin.kragh@ui.se
} 
Syftet med denna artikel är att explorativt undersöka hur Sveriges relationer till Ryssland utvecklats över tid; dels i ett längre tidsperspektiv, dels med hänsyn till utvecklingen under president Vladimir Putin. I fokus står det bilaterala utbytet i primärt tre dimensioner: politiska relationer, ekonomi och handel, och människorättsfrågor. Hur har Sveriges officiella relationer till Ryssland utvecklats under Putins tid vid makten? Hur har det svensk-ryska ekonomiska utbytet utvecklats under samma tid? Och hur passar denna utveckling av de bilaterala relationernas mönster in i ett längre tidsperspektiv?

Sammanfattningsvis har relationerna mellan Sverige och Ryssland i modern tid präglats av kontinuitet och stabilitet, vilket emellertid inte innebär att perioder av friktion också uppstått och kan uppstå framgent. Å ena sidan har Sverige och Ryssland en mer aktiv bilateral agenda än vad som ofta beskrivs, främst inom handel, investeringar och utbyte inom kultur och utbildning, och har så haft under lång tid. $\AA$ Andra sidan existerar ett antal frågor - som Ukrainakonflikten, EU:s östliga partnerskap, svenskt Natosamarbete och säkerhetsläget i Östersjön - där konkurrerande synsätt och anspråk mellan Sverige och Ryssland i dagsläget gör sig gällande. Därtill existerar svensk utrikespolitik i en multilateral kontext, som mer än under kalla kriget och tidigare epoker formar och sätter vissa ramar för det svensk-ryska utbytet. Under de senaste åren har Ryssland och Sverige bekräftat sina meningsskiljaktigheter, vilka sannolikt kommer att kvarstå givet att inga drastiska förändringar i de nuvarande politiska förhållandena mellan Ryssland och västmakterna äger rum.

Artikelns disposition är överlappande kronologiskt och tematiskt indelad. De två första avsnitten av artikeln tecknar en bild av de svensk-ryska bilaterala relationernas historiska utveckling fram till 1989-1991, respektive fram till 2014. Det tredje avsnittet beskriver utvecklingen inom handel, investeringar och affärsrelationer, följt av ett avsnitt om den vidare geostrategiska kontexten. De avslutande avsnitten beskriver de svensk-ryska relationerna idag och sammanfattar artikeln.

\section{Historisk bakgrund}

Framväxten av moderna stater under 1500-talet transformerade den europeiska kontinenten. I norra Europa upplöstes Hansan, monarkierna Danmark-Norge och Sverige konsoliderades, och 1547 kröntes Ivan IV till tsar över ett Moskvarike som nu också blev en europeisk stormakt. Fem årtionden av rivalitet kulminerade 1617 med freden i Stolbova, då Gustav II Adolf genom förvärv av ryska och polska regioner under drygt ett århundrade förvandlade Östersjön till ett svenskt innanhav och därmed monopoliserade dess handel - själva kärnan i vad som den polske kungen Sigismund II Augustus 1563 sägs ha benämnt ett dominium maris baltici. Ryssland retalierade genom öppnandet för handel med Storbritannien och Holland via grundandet av Archangelsk i norr, i syfte att undvika de svenska tarifferna, och under det stora nordiska kriget återvann det ryska tsardömet ett fotfäste i Östersjön med grundandet av Sankt Petersburg år 1703 (följande avsnitt baseras på Bring 2008; Chrispinsson 2011; Wahlbäck 1986). 
Efter Karl XII:s nederlag vid Poltava 1709 och freden i Nystad 1721 upphörde den svenska stormaktstiden, och även epoken då enskilda stormakter haft en dominerande roll i Östersjön. När landområdena från Kurland (i dagens Lettland) till östra Finland tagits under rysk kontroll, hade Peter I i allt väsentligt avslutat Sveriges hegemoniska roll. Med flera rivaliserande men likvärdiga strandstater kom den säkerhetspolitiska frågan nu att handla om maktbalans och vilka principer som skulle gälla för Östersjöns handel. Nystadsfreden grundlade den realpolitiska ordning som därefter alla svenska styrande haft att hantera, även om den inte nödvändigtvis accepterats, nämligen förhållandet att Tsarryssland - senare Sovjetunionen (1917/1924) följt av den Ryska federationen (1991) - förvisso varierat i vad avser militär kapacitet och politisk inriktning, men ändå hela tiden förblivit en i Östersjöregionen de nordiska småstaterna överlägsen stormakt.

Vare sig det styrande hattpartiet, som startade krig mot Ryssland 1741, eller Gustaf III, som upprepade misstaget 1788, accepterade de i grunden förändrade styrkerelationerna mellan Sverige och Ryssland. Vid båda tillfällena handlade det om försök att återta territorium som förlorats 1721 , och vid det första men inte det andra slutade krigen i ytterligare gränsjusteringar i rysk favör. Napoleonkrigen 1803-1815 hade vittgående konsekvenser för de nordiska länderna: Freden i Tilsit 1807 mellan Frankrike och Ryssland följdes två år senare av freden i Fredrikshamn och Sveriges avträdande av Finland till Alexander I. I Kielfreden 1814 avträdde den danska konungen i sin tur Norge till Sverige medan den svenske konungen avträdde Svenska Pommern och Rügen till Danmark, en svensk "nettovinst» som hade varit omöjlig utan den ryske tsarens stöd.

Framväxten av ett Preussen som regional stormakt i syd, och ett Ryssland i öst, motiverade under Karl XIV Johan en omläggning av Sveriges utrikespolitiska orientering som i allt väsentligt bestått fram till idag - närmare bestämt den strategi som syftar till en alliansfri säkerhetspolitik. Sonen Oscar I och sonsönerna Karl XV och Oscar II bekräftade den svenska alliansfriheten, och förklarade Sverige neutralt under olika konflikter. Den svenska politiken om att balansera rivaliserande stormakter å ena sidan, och slå vakt om neutraliteten å den andra, har emellertid inte varit entydigt med passivitet. Under Krimkriget tilläts den brittiska flottan 1854 nyttja svenska hamnar i syfte att tillintetgöra ryska fortifikationer på Åland. Dessförinnan hade Oscar I 1848 ställt upp svenska och norska trupper i Skåne och på Fyn; i syfte att bistå Danmark i händelse av att Preussen skulle hota det danska kärnlandet i konflikten om de tyskspråkiga hertigdömena Slesvig och Holstein (som dock förlorades 1864).

Mellan Alexander II:s "stora reformer» på 1860-talet och första världskrigets utbrott ökade det svensk-ryska utbytet inom handel, investeringar och kulturutbyte. Svensk verkstadsindustri var exportorienterad, och den ekonomiska geografin talade för Ryssland som viktig marknad. En rad svenska företag, som L.M. Ericsson, ASEA, Lux (senare Electrolux), Wicanders, SKF, AGA och Separator hade vid sekelskiftet 1900 etablerat en närvaro på den ryska marknaden. Ludvig Nobels mekaniska 


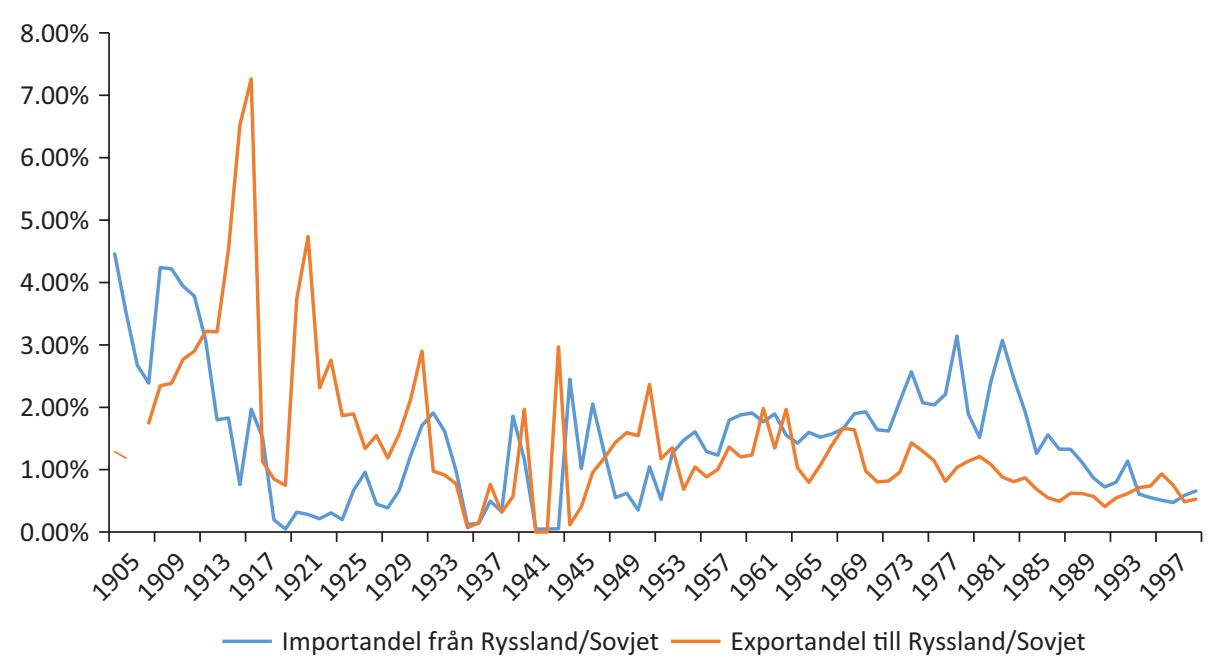

Figur 1. Svensk import från och export till Ryssland (Sovjetunionen), som procentuell andel av total svensk import och export, 1905-2000. ${ }^{1}$

verkstad i Sankt Petersburg, som hade grundats redan vid slutet av 1840-talet, följdes senare av Naftabolaget Bröderna Nobel som vid tidpunkten före första världskriget vuxit till ett av Rysslands största oljebolag. Som framgår av Figur 1 ökade den ryska marknadens andel av svensk export nästintill kontinuerligt från 1905 till 1917, från en nivå om cirka $1 \%$ år 1905 till över $7 \%$ år 1917 - den högsta andel av svensk export som till dagens datum uppmätts för Ryssland/Sovjetunionen. När Vladimir Lenin och bolsjevikerna i november 1917 usurperade makten i Ryssland och nationaliserade all utländsk egendom, förlorade svenskt näringsliv i ett slag investeringar till ett värde motsvarande minst 5,9\% av BNP detta år (Kragh 2014).

Den period av europeisk integration och relativt lugn som rådde mellan 1870 och 1914 skulle inte bestå, och Östersjön blev under såväl första som andra världskriget en förnyad geopolitisk konfrontationsyta. Det ryska imperiet bröt samman 1917, och ersattes av en sovjetmakt som skulle existera under sju årtionden. År 1920 träffade Sveriges allmänna exportförening med sin sovjetiska motpart en handelsuppgörelse, genom vilken Sverige som ett av de första europeiska länderna återupprättade de ekonomiska förbindelserna med Sovjetryssland, och 1924 erkände Sverige och en rad andra stater Sovjetunionen de jure. ${ }^{2}$ Den internationella fragmenteringen inten-

${ }^{1}$ Källa: Författarens beräkningar, samt flera årsupplagor av Statistisk årsbok för Sverige, tillgängliga på www.scb.se/sv_/Hitta-statistik/Historisk-statistik/Sok-publikationer-efter-amne/?Statistikserie= Statistisk+\%c3\%a5rsbok+(SOS+1914-)

${ }^{2}$ Regeringen Vladimir Lenin uppskattade 1920 års svensk-ryska handelsavtal. I det ryska handelskommissariatets tidskrift anmärktes det hur "Sverige kom att inta den första platsen i Sovjetrepublikernas handelsutbyte med utlandet och utgjorde det lufthål, genom vilket de kunde upprätthålla ekonomiska förbindelser med yttervärlden.» (Citerat i Wallensteen 1953: 430) 
sifierades emellertid; Josef Stalin och Adolf Hitler tog makten i sina respektive länder, och genom pakten Molotov-Ribbentrop den 23 augusti 1939 hamnade Finland, Estland, Lettland och Litauen i Moskvas "legitima intressesfär» - varpå Finland angreps militärt och de baltiska staterna ockuperades. Bland Östersjöns småstater var det enbart Sverige som under andra världskriget förblev förskonat från ockupation och/ eller territoriella förluster.

Det kalla kriget avslutades 1989-1991 utan krig, men en serie händelser dessförinnan kom att prägla de svensk-sovjetiska (ryska) relationerna. Å ena sidan i det kalla krigets inledande fas, med Riksbankens transferering av de baltiska centralbankernas guldreserver till Sovjetunionen 1940; den sovjetiska torpederingen av passagerarfartyget $S / S$ Hansa 1944 (med 84 omkomna); utlämningen av 167 baltiska soldater till Sovjetunionen 1945; kidnappningen av Raoul Wallenberg i Budapest 1945; kreditavtalet $1946 ;^{3}$ den sovjetiska militärens nedskjutning av underrättelseplanet $T p$-79 och sjöräddningsplanet $T p-49$ 1952. Detta följdes av händelser i det kalla krigets upplösningsfas, som den sovjetiska ubåten $S$-363:s (»U137») grundstötning i Karlskronas skärgård 1981; normaliseringen av de svensk-sovjetiska relationerna under Olof Palme 1985; och uppgörelsen 1987 om gränsdragningen mellan Sveriges och Sovjetunionens ekonomiska zoner i Östersjön mellan Gotland och Baltikum. Därtill kan läggas spionaffärerna Stig Wennerström (1969) och Stig Bergling (1979), samt Sveriges hemliga Natoförbindelser, vilka Moskva genom spionage hade varseblivit redan under kalla kriget (Dalsjö 2006; SOU 2002:108; Petersson 1994).

\section{Svensk-ryska relationer, 1991-2014}

Som en följd av den ryska demokratiseringen och närmandet mellan Ryssland och västländerna förbättrades också de svensk-ryska relationerna på 1990-talet. En rad världspolitiska omvälvningar under 1980-talet förändrade Sveriges externa miljö radikalt: avspänningspolitiken under Michail Gorbatjov och Ronald Reagan, undertecknandet av INF-avtalet mellan Sovjetunionen och USA 1987, och Berlinmurens fall 1989 följt av Sovjetunionens upplösning 1991. Den svenska regeringen inledde medlemskapsförhandlingar med EG 1993, och tog med anslutningen 1994 ett första steg bort från Sveriges tradition av neutralitetspolitik. Omläggningen av svensk utrikespolitik och landets försvarsorganisation följdes av ett närmare samarbete med Nato, deltagande i EU:s snabbinsatsstyrkor, prioritering av internationella militära insatser över nationellt invasionsförsvar, och en solidaritetsdeklaration inom ramarna för ett utvidgat nordisk-baltiskt samarbete (se Doeser 2010; Winnerstig 2014). Som en konsekvens har Sveriges utrikespolitik därmed också kommit att inordnas i en utpräglat multilateral ordning, där Sveriges relationer till Ryssland i vissa hänseenden också samordnas med i synnerhet EU.

${ }^{3} 1946$ års kreditavtal ersatte det aldrig implementerade kreditavtalet från 1940. Ett nytt handelsavtal undertecknades 1954. 
President Boris Jeltsins statsbesök i Stockholm 1997 var det första sedan Nikita Chrusitjovs 1964, som i sin tur hade varit det första och enda sovjetiska officiella besöket i Sverige. Besök på hög nivå mellan Sverige och Ryssland har varit förekommande historiskt sett men aldrig intensivt. Chrusitjovs Sverigeresa var ett försenat svar på statsminister Tage Erlanders besök i Sovjetunionen 1956, en visit som Erlander återupprepade 1965. Olof Palme besökte Sovjetunionen vid två tillfällen, 1970 och 1976, och skulle ha avlagt ett besök även 1986 (besöket genomfördes av Ingvar Carlsson). Sovjetiska regeringschefen Aleksej Kosygin avlade Sverigebesök 1968 och 1973, likt senare Nikolaj Ryzjkov 1988. Långt dessförinnan hade Oscar II avlagt statsbesök i Ryssland 1875, och Nikolaj II det enda officiella tsarryska statsbesöket i Sverige 1909. Såväl statsminister Göran Persson (1999) som Fredrik Reinfeldt (2010) har avlagt besök i Ryssland. Därtill har Carl XVI Gustaf avlagt statsbesök i Sovjetunionen 1978, i Ryssland 2001, samt ett ytterligare besök genom Ingenjörsvetenskapsakademin 2007. ${ }^{4}$ Vladimir Putin har som president aldrig avlagt något statsbesök i Sverige, men han besökte EU-toppmötet i Göteborg 2001 (vilket även president Dmitrij Medvedev gjorde 2009) och besökte i egenskap av premiärminister regeringen Reinfeldt 2011 (Lagerqvist 2004; Pravda 1976; Hagström-Frisell \& Oldberg 2009). ${ }^{5}$

Att döma av den svenska regeringens utrikespolitiska deklarationer har frågor om mänskliga rättigheter och internationell rätt stått nästintill oavbrutet i fokus för de svensk-ryska relationerna under 2000-talet - något som varit en källa till irritation i Kreml. Svenska regeringar har kritiserat Ryssland för utvecklingen avseende det krympande utrymmet för fria medier, situationen i Tjetjenien, morden på Anna Politkovskaja och Aleksandr Litvinenko, och kriget med Georgien 2008. Men Sverige har även uppmuntrat till en fördjupad samverkan mellan Ryssland och EU, ett ryskt medlemskap i WTO, samt ett nukleärt nedrustningsavtal mellan Ryssland och USA; och två svensk-ryska militärövningar - Snöflinga 1 och Snöflinga 2 - genomfördes 2006 och 2007 (Svenska Dagbladet 2007a; Regeringens deklaration 2009). Vidare har svenska pekpinnar riktats även mot andra forna sovjetrepubliker, däribland Azerbajdzjan, Ukraina och Belarus, och vissa år - exempelvis under åren 2009 till 2012 - har kritiken mot Ryssland varit förhållandevis nedtonad i jämförelse med kritiken mot andra forna sovjetrepubliker. ${ }^{6}$

\footnotetext{
${ }^{4}$ Statsminister Göran Perssons deltog tillsammans med ett femtiotal stats- och regeringschefer i det ryska högtidlighållandet av Segerdagen i Moskva den 9 maj 2005.

${ }^{5}$ Premiärminister Michail Kasianov avlade officiell visit i Sverige 2001.

${ }^{6}$ Jämför exempelvis beskrivningarna av Belarus respektive Ryssland i 2010 års utrikespolitiska deklaration. "Situationen i Vitryssland är alltjämt oroande inte minst vad gäller respekten för mänskliga rättigheter. Regeringens stöd för ett öppet och demokratiskt Vitryssland fortsätter. Även samarbetet med södra Kaukasus måste stärkas. Georgiens territoriella integritet och demokratiska utveckling är viktiga också för den vidare regionen. Sverige välkomnar den ryske presidentens uttalanden om vikten av en fungerande rättsstat och en omfattande modernisering av det ryska samhället. Vi hoppas att det snart ska vara möjligt att välkomna även Ryssland som medlem i WTO.» (se Regeringens deklaration 2010).
} 
Den svenska kritiken av Rysslands inrikespolitiska utveckling har lyfts fram som en förklaring till att en rysk president inte avlagt statsbesök i Sverige sedan 1997. Andra skäl till att relationerna förblivit ansträngda har varit Sveriges vägran att utlämna två tjetjener anklagade för terrorbrott (»banditer» enligt den ryska regeringen), eftersom Ryssland inte bedömts erbjuda garantier i enlighet med europeisk rättstradition; ${ }^{7}$ svensk vägran att stänga ned den av Ryssland terroriststämplade hemsidan Kavkaz Center, baserad hos ett svenskt serverföretag; och svenskt stöd till Estland 2007, med anledning av den estnisk-ryska konflikten kring flytten av ett sovjetiskt krigsmonument i Tallinn. Den sannolikt mest seriösa diplomatiska dispyten före Krimannekteringen 2014 skedde sex år dessförinnan, då Carl Bildt (under sin tid som Europarådets ordförande) fördömde Rysslands militära intervention i Georgien 2008 och drog paralleller mellan de ryska officiella bevekelsegrunderna - att »skydda» personer med ryska pass eller rysk nationalitet - och Adolf Hitlers rättfärdigande av sitt agerande för att ta Sudetenland från Tjeckoslovakien 1938 (Hagström-Frisell \& Oldberg 2009; Sveriges Radio 2008).

Med viss regelbundenhet har enstaka och oförutsägbara incidenter inbegripandes svenska företrädare och medborgare inverkat på de svensk-ryska relationerna. År 2007 attackerades den svenske ambassadören Johan Molanders bil av "Nasji»-ungdomar utanför Estlands ambassad i Moskva - något som föranledde en officiell protest från svenska UD till den ryske ambassadören. En liknande händelse utspelade sig 2016, då Sveriges Radios Rysslandskorrespondent Maria-Persson Löfgren misshandlades under en genomresa i ryska Ingusjien, något som även det föranledde en svensk officiell markering (Sveriges Radio 2007; Regeringen 2016). Däremellan hade en svensk miljöaktivist, tillsammans med 29 andra besättningsmän ombord Greenpeace-fartyget Arctic Sunrise, arresterats av ryska specialförband under en protestaktion på internationellt vatten mot rysk oljeutvinning i Arktis (samtliga frisläpptes två månader senare) (Svenska Dagbladet 2013a).

Sverige har sedan 1992 stöttat aspekter som demokrati, studentutbyten, och miljöinvesteringar i Ryssland, om än i termer av resursfördelning sedan ett antal år tillbaka på en lägre nivå än för flera andra postsovjetiska stater. År 2006, när det konventionella biståndet till Ryssland via biståndsanslaget upphörde, hade svenska skattebetalare enligt en uppskattning finansierat ryska utvecklingsprojekt till ett totalbelopp om cirka 3,8 miljarder kronor sedan sovjetsystemets fall (se Ingelstam 2017: 24-25; Uggla 2010). Stöd via andra utgiftsområden i statsbudgeten har dock fortsatt; 2015 mottog ryska organisationer totalt 64 miljoner kronor, varav 57,6 miljoner kronor utgjordes av demokratistöd. Detta kan jämföras med de andra postsovjetiska staterna Ukraina (256 miljoner kronor), Belarus (120 miljoner kronor), Georgien (112 miljoner kronor) och Moldavien (97,9 miljoner kronor). Enbart två mottagarländer i regionen mottog 2015 mindre stöd än

${ }^{7}$ Ryska UD:s uttalande om det svensk-ryska utlämningsärendet (se MID 2008). 
Ryssland, nämligen Armenien (10,2 miljoner kronor) och Azerbajdzjan (9,4 miljoner kronor). ${ }^{8}$ Sverige har även skickat separat stöd till Ryssland via exempelvis Miljödepartementet i syfte att främja kärnkraftssäkerhet - mellan åren 2009 och 2013 avsattes där cirka 220 miljoner kronor för ändamålet (Svenska Dagbladet 2013b).

Den inrikespolitiska utvecklingen i Ryssland sedan 2012 - med restriktioner av mötesfriheten, förbud mot "homosexuell propaganda», och en lag om utländsk finansiering som innebär att organisationer som tar emot ekonomiskt stöd från utlandet och bedöms bedriva "politisk verksamhet» måste registrera sig som "utländska agenter» - har haft begränsande konsekvenser också för det svensk-ryska utvecklingssamarbetet. Det Nordiska ministerrådet, som finansieras av Danmark, Finland, Island, Norge och Sverige och som under 1990-talet etablerat närvaro i Sankt Petersburg och Kaliningradregionen, förklarades av ryska myndigheter 2014 som "utländsk agent", varför de nordiska samarbetsministrarna valde att suspendera all lokal verksamhet på obestämd framtid (Sveriges Radio 2015). Nedstängningen av det Nordiska ministerrådets verksamhet var inte unik, utan en logisk följd av en större rysk myndighetsoffensiv mot såväl inhemska som utländska organisationer som i landet verkat för främjandet av demokrati och rättsstatlighet (Daucé 2015; Flikke 2015). En annan rysk inrikespolitisk fråga som uppmärksammats i Sverige sedan 2016 är det försämrade säkerhetsläget för HBTQ-personer i Tjetjenien, en fråga som Sverige tillsammans med Storbritannien, Frankrike, Tyskland och Holland tog upp våren 2017 med utrikesminister Sergej Lavrov (Svenska Dagbladet 2017a).

\section{Handel, investeringar och energi}

De svensk-ryska ekonomiska relationerna går tillbaka till 900-talet, då svenska handelsmän - varjager - handlade och plundrade längs utmed det nätverk av floder som förbinder Östersjön med Svarta havet och slutligen Konstantinopel (Istanbul) och Kaspiska havet. Ryssland har under senmedeltiden haft ett nästintill konstant överskott $i$ handelsbalansen med Västeuropa, som från öst importerade lyxartiklar som pälsar, persiskt silke och kaviar, men också råvaror för den brittiska och holländska skeppsindustrin. Efter freden i Stolbova 1617 tilläts ryska handelsmän etablera sig i Ryssgården i Stockholm, och svenska handelsmän har verkat i Novgorod, Pskov och vid Svenska gården i Moskva, tillika plats för den mellan 1631 och 1712 permanenta beskickningen i Moskva. Vid 1800-talets början var Ryssland och Sverige Europas dominerande exportörer av järn, och i slutet av samma århundrade hade svensk verkstadsindustri, som vi såg ovan, börjat söka sig till den ryska marknaden (Attman 1944; Hildebrand 1958; Jangfeldt 1998).

${ }^{8}$ Statistik för svenskt bistånd finns samlat på www.openaid.se. 
Ekonomisk geografi talar för Ryssland som en viktig marknad för svenskt näringsliv, men den ryska/sovjetiska marknaden har i relativa termer minskat $i$ betydelse för svensk export över tid. Som framgår av Figur 1 ovan, har den ryska marknadens signifikans för svenska företag fluktuerat under 1900-talet, men i relativa termer aldrig återhämtat sig till nivåerna från åren före 1917 då mellan 3-7 $\%$ av svensk export skickades till Tsarryssland. Sovjetunionen etablerade sig som en betydande exportör av olja under 1970-talet, bland annat till Sverige, men den autarki som präglade den sovjetiska ekonomin begränsade import från det »kapitalistiska blocket». Först på 1990-talet kom den svenska exporten till Ryssland att öka något, även om den ryska marknaden likväl inte utgjort mer än cirka 1-2\% av svensk export totalt.

Det kvalitativa skiftet i modern tid skedde mellan 1999 och 2008, då stigande världsmarknadspriser för olja och naturgas, i kombination med vissa marknadsfrämjande reformer i Ryssland, stimulerade handel och investeringar. Svenska direktinvesteringar i Ryssland ökade från 0,5 miljarder USD år 2007 till cirka 2 miljarder per år från 2008 till 2012 - en nivå av investeringar som väsentligt överskred de danska, finska och norska investeringarna i Ryssland (se Figur 2). En rad svenska stora och mellanstora företag, som Scania, Volvo, Oriflame, Pripps, Tele 2, IKEA, MTG och H\&M, etablerade närvaro i Ryssland. Vad handeln anbelangar belöpte sig i januari månad 1998 svensk Rysslandsexport till cirka 0,25 miljarder SEK; i samma tidsperiod 2008 hade den ökat till cirka 3,6 miljarder SEK. Sedan 2009 har den ryska marknaden successivt krympt, till mellan 1-2 miljarder SEK per månad, medan importen från Ryssland har förblivit stabil. Svensk import från Ryssland domineras alltjämt av ett enda varuslag, olja - oljans andel ökade från cirka $17 \%$ av kronvärdet på den totala importen från Ryssland år 2000 till 64 \% år 2016 (se Figur 3, Figur 4 och Figur 5). Ryskt industriellt ägande i Sverige, med undantag för Rusals ägande av den svenska aluminiumproducenten Kubal i Sundsvall, är till synes obetydligt. ${ }^{9}$

Svenska direktinvesteringar i Ryssland har under perioden 2013 till 2016 minskat till cirka 0,12-0,17 miljarder USD per år, och 2013 var svenska direktinvesteringar i Ryssland negativa, cirka -1,2 miljarder USD. Nedgången innebär att svenska direktinvesteringar i Ryssland numera ligger på ungefär samma nivå som för övriga nordiska länder. Den huvudsakliga anledningen till utvecklingen, såvitt den ryska centralbanksstatistiken indikerar, förefaller vara att svenska företag började att repatriera istället för att återinvestera sina vinster (se Figur 6). Det är i sammanhanget noterbart att svenska företag kom att minska sin exponering på den ryska

${ }^{9}$ Det finns ingen samlad offentlig statistik om utländskt ägande i Sverige. Ett ytterligare exempel på ryskt ägande i Sverige är telekomföretaget Net1, som ägs av oligarken Leonard Blavatnik (som emellertid är amerikansk medborgare). Net1 har intressen i 450-bandet i Sverige, en frekvens som används av viktiga säkerhetsfunktioner, till exempel polis, räddningstjänst, kustbevakning och kärnkrafts- och elnätsövervakning (se Veckans Affärer 2014). 


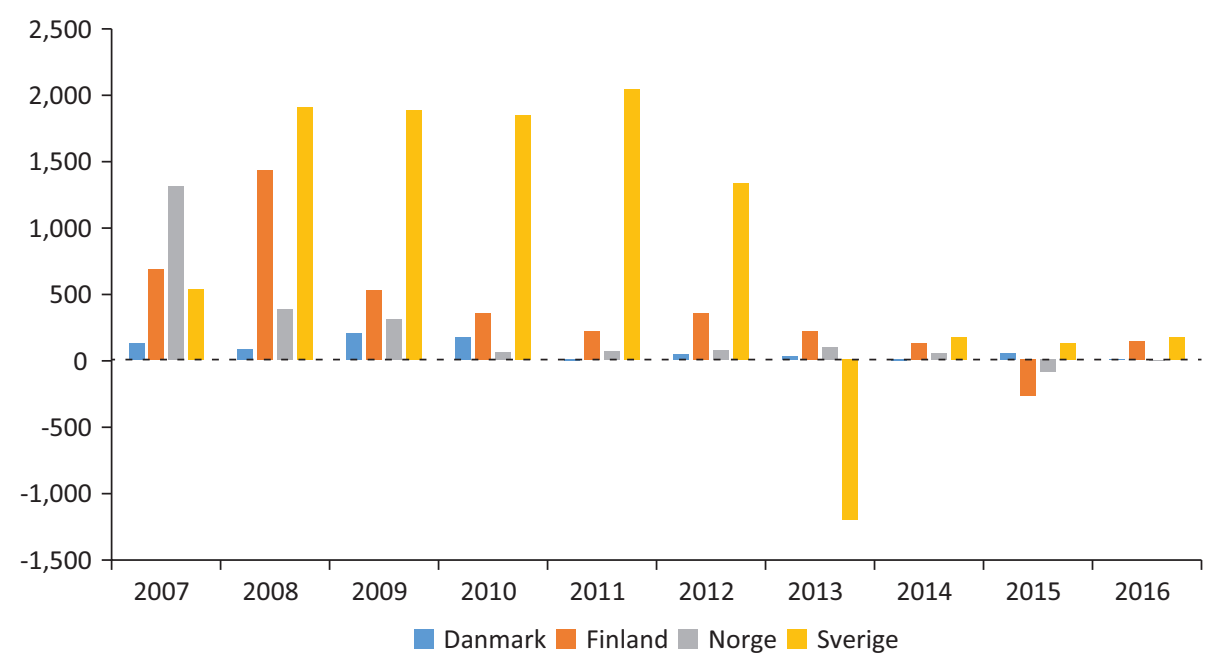

Figur 2. Danska, finska, norska och svenska direktinvesteringar i Ryssland, 2007-2016 (miljoner USD)..$^{10}$

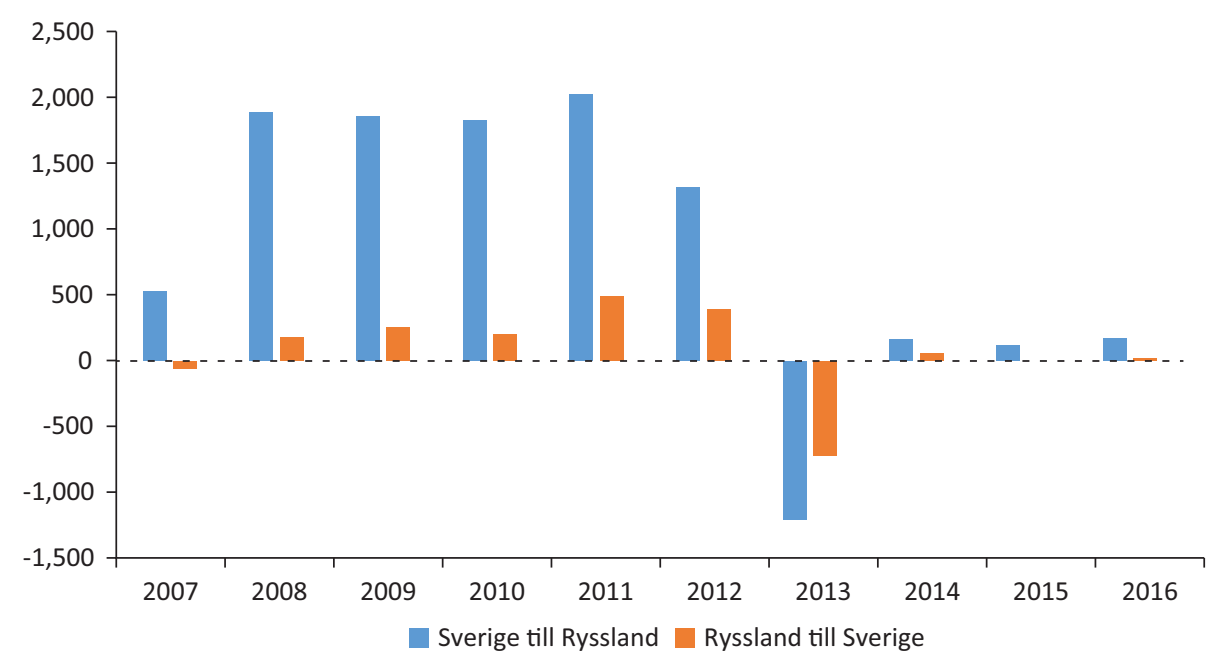

Figur 3. Svenska direktinvesteringar i Ryssland, och ryska direktinvesteringar i Sverige, 20072016 (miljoner USD). ${ }^{11}$

marknaden redan ett år innan Krimannekteringen, sanktionsregimerna, och det halverade världsmarknadspriset på olja - vilket indikerar att nedgången inte primärt kan sägas ha geopolitiska bevekelsegrunder. De exakta skälen till nedgången är inte enkla att utreda, men en spekulativ förklaring kan vara Vladimir Putins återkomst som president hösten 2012, vilket hos investerare uppfattades som en signal att det

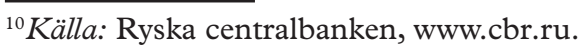

${ }^{11}$ Källa: Ryska centralbanken, www.cbr.ru. 


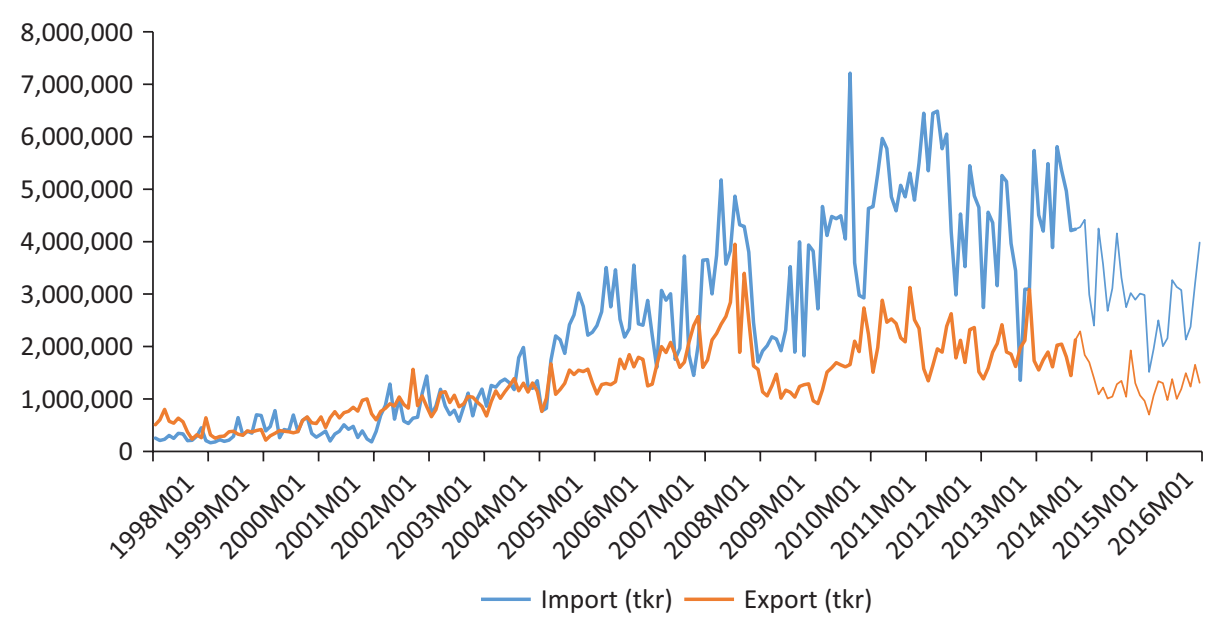

Figur 4. Svensk import från och export till Ryssland, 1998-2016 (tusen SEK). ${ }^{12}$

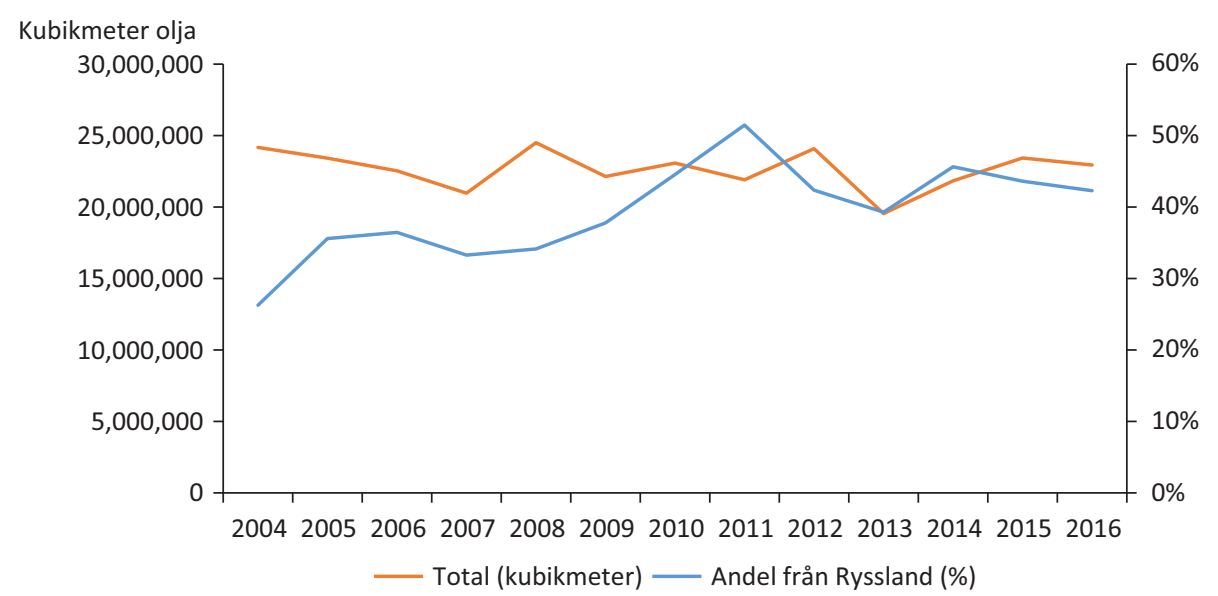

Figur 5. Svensk import av olja (kubikmeter) och procentuell andel från Ryssland, 2004-2016. ${ }^{13}$

ekonomiska klimatet inte skulle förbättras inom överskådlig framtid. ${ }^{14}$ Ytterligare en förklaring kan vara de restriktioner på utländskt ägande inom "strategiska» sektorer, vilka införts stegvis under 2000-talet, och som tvingade bland andra svenska MTG (media) och Tele2 (telekom) att 2014 avyttra sina ryska bolag. I vilken utsträckning de ömsesidigt implementerade sanktionsregimerna mellan EU/USA och Ryssland sedan 2014 har haft en effekt på svenska företag som grupp är svårt att utreda, även

${ }^{12}$ Källa: Statistiska centralbyrån, www.scb.se.

${ }^{13}$ Källa: Svenska Petroleum och Biodrivmedel Institutet, www.spbi.se.

${ }^{14}$ Denna förklaring har framförts av exempelvis Guriev (2013). 
om enskilda företag påtalat de negativa konsekvenserna av Rysslands livsmedelssanktioner, och den psykologiska effekten på marginalen kan antas ha motverkat investeringsbenägenheten.

Svensk import av rysk olja ökade från cirka $26 \%$ till $42 \%$ av den totala oljeimportvolymen under åren 2004-2016, vilket gör Ryssland till Sveriges ohotat största leverantör före Danmark, Norge, Storbritannien, Iran och Venezuela (se Figur 7). I motsats till frågan om naturgas - som Sverige ej är beroende av - har olja emellertid aldrig varit en aspekt i den säkerhetspolitiska diskussionen. Såväl Nordstream 1 som Nordstream 2 - två rysk-tyska naturgasledningar i Östersjön som passerar svensk ekonomisk zon - har båda varit politiskt kontroversiella. Sveriges regering dröjde med godkännandet av Nordstream 1 (2009), med hänvisning till ett behov av att de miljörelaterade aspekterna utreds, och Nordstream 2 har ur säkerhetspolitisk synpunkt ifrågasatts om än inte hindrats av den svenska regeringen. ${ }^{15}$ Med undantag av ett inspel från intresseorganisationen Svenskt Näringsliv om att en rörgren av Nordstream 1 också med fördel kunde dras till Sverige, har svenskt intresse för rysk naturgas varit svagt (Dagens Nyheter 2006). ${ }^{16}$

Den svenska utgångspunkten har varit att $\mathrm{FN}$ :s havsrättskonvention, enligt vilken kabel- och rörläggning $i$ internationellt vatten och ekonomisk zon är tillåten, ska gälla även för Östersjön. Det har varit den svenska regeringens åsikt avseende

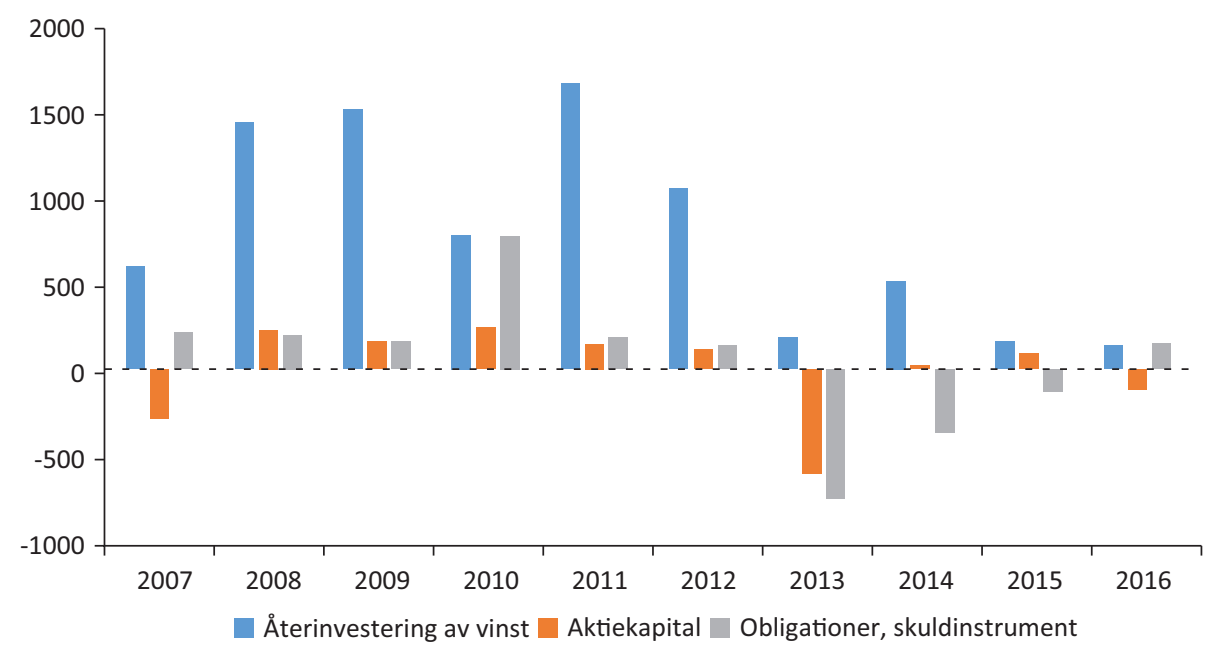

Figur 6. Svenska direktinvesteringar i Ryssland, 2007-2016, uppdelat i olika kategorier (miljoner USD) $)^{17}$

${ }^{15} \mathrm{På}$ Försvarsmaktens inrådan har emellertid Slite hamn vid Gotland inte upplåtits åt Nordstreams rörläggningsfartyg.

${ }^{16}$ År 2007 investerade Nordstream 100 miljoner SEK på Gotland i olika projekt (Svenska Dagbladet 2007).

${ }^{17}$ Källa: Ryska centralbanken, www.cbr.ru. 


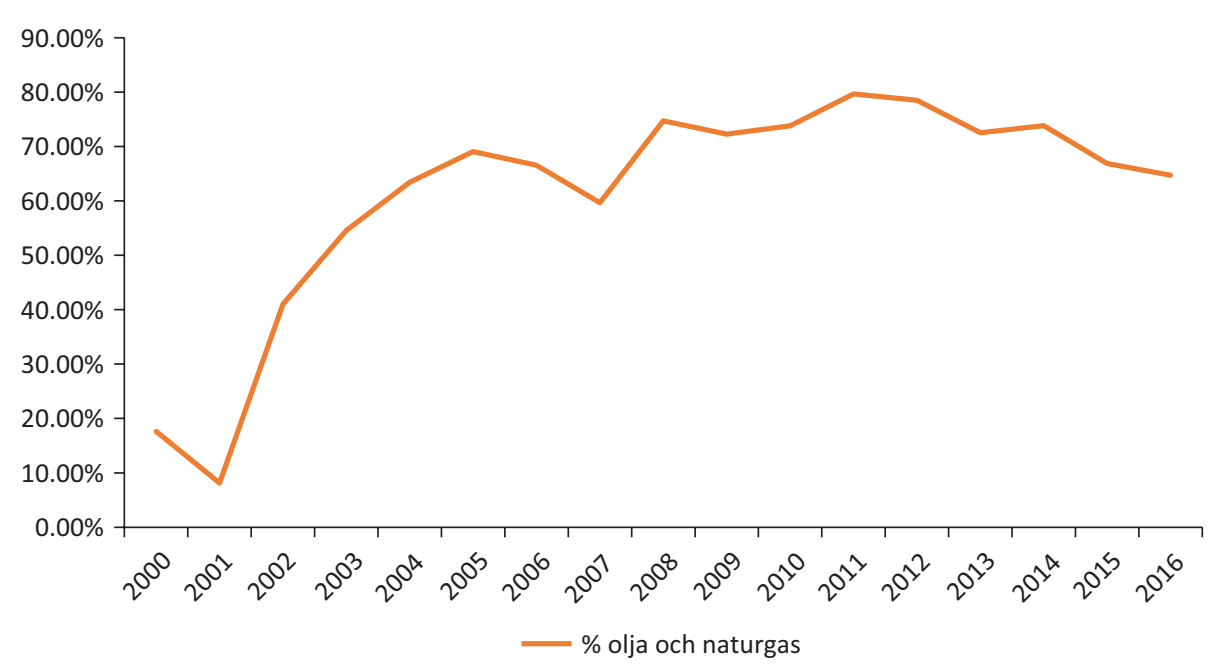

Figur 7. Oljans och naturgasens andel av svensk import från Ryssland, 2000-2016. ${ }^{18}$

Nordstream, och kom att aktualiseras i och med byggandet av Nordbalt, en sjökabel som sedan 2016 förbinder de svenska och litauiska elnäten. År 2015 hindrade (alternativt hotade) ryska örlogsfartyg de svenska och litauiska elkabelläggningsfartygen i sitt arbete på internationellt vatten, något som föranledde svenska UD att avlägga en formell protest till ryska myndigheter (Dagens Nyheter 2015).

En separat affärsrelaterad fråga som inverkat på de svensk-ryska relationerna är den juridiska konflikt mellan en tysk affärsman, Franz Sedelmayer, och den ryska staten, som fătt konsekvenser i bland annat Sverige och 2011 avgjordes i Högsta Domstolen (HD). Sedelmayer, som sedan 1990-talet haft en oreglerad fordran på den ryska staten, förklarades enligt HD berättigad att kräva utmätning av ett sjuvåningshus på Lidingö utanför Stockholm, som vid tidpunkten användes av Rysslands handelsrepresentation och ägdes av ryska staten. Trots att fastigheten såldes 2014 på exekutiv auktion till nya ägare, har Rysslands ambassad vägrat evakuera sin personal, vägrat betala hyra för fastigheten, samt förskansat fastigheten med bom, en skylt och betongsuggor. Ryska UD har kritiserat HD-domen som illegitim och en "allvarlig belastning» för de svensk-ryska relationerna, och frågan förblir olöst (Aftonbladet 2017). ${ }^{19}$ Svenska UD har dock bekräftat den ryska personalens diplomatiska immunitet, vilket i praktiken gett upphov till en status quo-situation där kronofogden varit berättigad att sälja fastigheten men inte kunnat avhysa de diplomater som alltjämt ockuperar fastigheten, samtidigt som den ryska statens skulder till kronofogden växer.

${ }^{18}$ Källa: Statistiska centralbyrån, www.scb.se.

${ }^{19}$ Ryska UD:s officiella uttalande om HD-domen (se RUSEMB 2017.) 


\section{Från det östliga partnerskapet till Krimannekteringen}

Det östliga partnerskapet, officiellt lanserat 2009 i Prag, har varit en svensk utrikespolitisk prioritet under såväl borgerliga som socialdemokratiska regeringar. Partnerskapet är också en illustration av hur de svensk-ryska relationerna under 2000-talet kommit att bli inbäddade i och förbundna med EU:s relationer till Ryssland. Ursprungligen initierat av Sverige och Polen 2008 som en motsvarighet till Medelhavsunionen och Barcelonaprocessen i söder, syftade det östliga partnerskapet till att förstärka EU:s östliga dimension - primärt genom erbjudande av associationsavtal till Armenien, Azerbajdzjan, Georgien, Moldavien, Ukraina och Belarus. Från svenskt perspektiv var det östliga partnerskapet officiellt en fråga om att bidra till regionens utveckling, stabilitet och säkerhet, delvis motiverat av det rysk-georgiska kriget i augusti 2008 men också som ett politiskt projekt för att mildra effekterna av den globala finanskrisens utbrott samma år (Bildt 2008). ${ }^{20}$

Rysslands motstånd till det östliga partnerskapet kan beskrivas som en situation med två konkurrerande anspråk inom världspolitiken. Vad som från Bryssel betraktats som ett ömsesidigt förankrat integrationsprojekt självständiga stater emellan, där deltagande är frivilligt för den enskilda staten, har från Moskva förklarats utgöra ett exempel på geostrategisk konfrontation. Enligt ryska ledare var det östliga partnerskapet från början ett försök att utvidga EU:s roll på bekostnad av ryska intressen, och att tvinga forna sovjetstater till att fjärma sig från Ryssland. "Vi anklagas för att ha en intressesfär», lamenterade Rysslands utrikesminister Sergej Lavrov i mars 2009 på ett EU-möte. "Men vad är det östliga partnerskapet, om inte ett försök att utvidga EU:s intressesfär... Är detta demokratistöd eller utpressning? Det handlar om att dra länder från positioner de vill inta som suveräna stater.» (Valenita 2009). Kremls instinkt att betrakta det östliga partnerskapet i geostrategiska termer kulminerade februari 2014 i Krimannekteringen och militär intervention i östra Ukraina (för en sammanfattning av händelserna, se Tsygankov 2015). Den ryska reaktionen på Ukrainas "Majdanrevolution» 2014, utlöst av den dåvarande presidenten Viktor Janukovitjs helomvändning i sista stund och beslutet att ej underteckna ett färdigförhandlat associationsavtal med EU i november 2013, är den i modern tid centrala vattendelaren i de svensk (väst)-ryska relationerna. I 2014 års svenska utrikesdeklaration, presenterad 19 februari samma år, förklaras det hur "[...] vi ser, i land efter land i vårt östeuropeiska grannskap, hur oacceptabla ryska påtryckningar och hot utifrån nollsummespelets felaktiga logik, riktas mot dem som söker närmare samarbete med EU» (Regeringens deklaration 2014). Två år senare, i 2016 års deklaration, har det förändrade säkerhetsläget i Europa satt ett definitivt avtryck med fokus på folkrätten,

\footnotetext{
${ }^{20}$ En viktig säkerhetspolitisk förändring skedde 2009, då den svenska regeringen anammade en solidaritetsdeklaration som säger att Sverige inte kommer att förhålla sig neutralt i händelse av att angrepp skulle ske mot annan nordisk stat eller EU-medlem, samt att Sverige i sin tur förväntar sig stöd i händelse av att Sverige skulle påverkas. Vidare gavs den svenska Försvarsmakten i uppdrag att träna på att ge såväl som motta militärt stöd (Hugemark 2011).
} 
Ukrainas territoriella integritet, och det ryska inträdet på den syriska krigsskådeplatsen i september 2015:

»Rysslands olagliga annektering av Krim och militära närvaro i östra Ukraina utgör flagranta brott mot folkrätten. Detta är den största utmaningen mot den europeiska säkerhetsordningen sedan kalla krigets slut. Sanktionerna mot Ryssland måste vara kvar till dess att Minskavtalet uppfyllts. Ukraina ska åter kunna kontrollera sina internationellt erkända gränser. Det är viktigt att bidra till ett starkt, demokratiskt och stabilt Ukraina. Sverige stödjer bilateralt och genom EU den ukrainska regeringens reformarbete. (...) Det ofattbara mänskliga lidandet i Syrien är en katastrof och ett allvarligt hot mot hela regionens säkerhet. Halva den syriska befolkningen är på flykt i eller utanför landet. Assadregimens liksom Rysslands bombningar av oppositionen är oacceptabla och hotar den sköra fredsprocessen.» (Regeringens deklaration 2016)

\section{De svensk-ryska relationerna idag}

De svenska synpunkterna på Ryssland tydliggörs i den utrikespolitiska deklarationen 2017, som ytterligare skärpte formuleringarna i jämförelse med föregående år men samtidigt uttryckte en önskan om att relationerna ska normaliseras. Deklarationen fördömer Rysslands militära agerande gentemot Georgien och Ukraina, belyser dess bruk av "desinformation och påverkansoperationer», och kritiserar den inrikespolitiska utvecklingen mot "auktoritärt styre, ett civilsamhälle under press, och bristande respekt för mänskliga rättigheter.» Sanktionerna mot Ryssland legitimeras med hänsyn till Ukrainas suveränitet och territoriella integritet, vars EU-integration Sverige uppmuntrar. Vidare betonas återigen betydelsen av internationell rätt: "Grunden för vår hållning är viljan att värna folkrätten och den europeiska säkerhetsordningen.» Slutligen upprepas behovet av en aktiv bilateral agenda mellan Sverige och Ryssland, en agenda som syftar till politisk dialog, "samarbete istället för konfrontation", och främjande av kontakter mellan medborgare. Barentsrådet och Östersjöstaternas råd, med sina regionala fokusområden, identifieras som centrala institutioner för ändamålet (se Regeringens deklaration 2017).

När utrikesminister Margot Wallström besökte sin motpart Sergej Lavrov i Moskva i februari 2017, var detta det första fullödiga ministermötet sedan 2012. De svensk-ryska relationerna har av ryska företrädare beskrivits som de sämsta sedan kalla kriget - med tillägget att denna försämring beror på svensk inställning. "Ett brutet samarbete på en rad olika praktiska områden och frysningen av bilaterala mekanismer», argumenterade Lavrov när han mötte Wallström, "har gjorts på svenskt initiativ» (Dagens Nyheter 2016; Yle 2017). Vad han sannolikt kan ha syftat på, var det svenska beslutet i april 2014 att avbryta såväl det militära samarbetet ("arrangemangsplanen»), som utbytet mellan ländernas militärattachéer. ${ }^{21}$

\footnotetext{
${ }^{21}$ Motstridiga uppgifter om det avbrutna militära samarbetet mellan Sverige och Ryssland har florerat i svensk media. (se SVT Nyheter 2015), som exempelvis antyder att arrangemangsplanen avbröts 2014 på ryskt initiativ.
} 
Uppehållet i besöksutbyten på "hög nivå» mellan 2014 och 2017 var ett ovanligt men inte exempellöst beslut inom ramarna för de svensk-ryska relationerna. En liknande situation infann sig senast 1983, i efterspelet till Sveriges formella protest "mot de grova kränkningar av Sveriges territorium till vilka den sovjetiska marinen gjort sig skyldig», men som Moskva officiellt bestred hade ägt rum (se Andrén 1996:116).

De skarpare formuleringarna i 2017 års utrikespolitiska deklaration bottnar i de senaste årens mer negativa säkerhetspolitiska utveckling kring Östersjön: Under påskveckan 2013 flög ryska bombflygplan i riktning mot svenskt territorium, utan att det svenska flygvapnet hade förmåga att reagera (Svenska Dagbladet 2013c); året därpå närmade sig ett ryskt stridsflygplan ett civilt SAS-plan i rutt mellan Sverige och Danmark (Svenska Dagbladet 2014); och misstankar om en ubåtskränkning i svenskt territorialvatten 2014 ledde till förnyade diskussioner om Rysslands eventuella roll. Spridningen av desinformation och falska dokument, i syfte att påverka svensk opinion och beslutsfattande, har bland annat kunnat kopplas till ryska statliga medier (Kragh \& Åsberg 2017).

De ökade motsättningarna återspeglas även inom andra områden. En tredjedel av Rysslands ackrediterade diplomater i Sverige, enligt Säpos årsrapport 2015, är underrättelseofficerare som bedriver spionage och krigsförberedande åtgärder mot svenska intressen (Dagens Nyheter 2016). Situationen för svenska journalister och diplomater verksamma i Ryssland sägs av källor inom Säpo också ha försvårats (Expressen 2014). Omständigheterna påminner om 1980-talet, då det avslöjades hur den svenska ambassaden i Moskva - $\mathrm{i}$ likhet med andra ambassader - buggades av KGB med hjälp av utrustning inbyggd i väggar, golv och tak från tidpunkten då fastigheten hade uppförts 1972 (Lénart 2008; Vestkusten 1987). Regimtrogna ryska medier har även anklagat Sverige för att underblåsa försök till "regimskifte» i landet, bland annat i ett inslag 2012 som namngav och pekade ut svenska diplomater som den ryska oppositionens "svenska familj» (läs: hemliga finansiärer). Via Facebook och Twitter har den ryska ambassaden i Sverige sedan 2014 förhållandevis frivolt kritiserat och recenserat svenska politiker, journalister och forskare, som man menar uttryckt sig felaktigt eller onyanserat om Ryssland - ett tonläge i den officiella diplomatin som Ryssland tidigare inte uppvisat (Komsomolskaja Pravda 2012; Expressen 2015).

Det svenska folkets inställning till utvecklingen i Ryssland har under de senaste åren blivit mer negativ. Enligt den årliga SOM-undersökningen vid Göteborgs universitet, har andelen svenskar som säger sig vara "ganska oroliga" eller "mycket oroliga» över situationen i Ryssland ökat från 53 \% till 80 \% mellan 2013 och 2014 (Dagens Nyheter 2015b). I en global jämförelse hör svenskarnas attityder gentemot Ryssland och dess ledare till de mest negativt predisponerade i Europa. Enligt 2017 års Pew Global-undersökning sade sig $87 \%$ av de tillfrågade svenskarna sakna förtroende för att president Vladimir Putin will do the right thing regarding world affairs, mot en europeisk median om $78 \%$. Endast tre andra länders befolkningar hade ett 
lägre förtroende för Putin, nämligen Polen (89 \%), Spanien (88 \%) och Holland (87\%). Även bilden av Ryssland som land är ogynnsam, där $78 \%$ av svenskarna uppger sig ha en negativ syn på landet, mot ett EU-genomsnitt på 61 \%. Frågan om mänskliga rättigheter förefaller viktig: på frågan Do you think the government of Russia respects the personal freedoms of its people?, svarade $91 \%$ av de tillfrågade svenskarna nej, och enbart $6 \%$ ja. Det svenska folkets låga förtroende för den ryske presidenten återspeglas dock inte rakt av i den upplevda hotbilden: "enbart» $39 \%$ av de tillfrågade svenskarna betraktade Ryssland som a major threat to their country, i jämförelse med $65 \%$ i Polen, $47 \%$ i Spanien och $44 \%$ i Holland (Vice 2017).

Moskvas synpunkter på de svensk-ryska relationerna sedan 2014 begränsar sig i huvudsak till ett fåtal vidare geostrategiska frågor: frågan om ett svenskt Natomedlemskap (eller närmande till Nato), EU:s sanktionsregim gentemot Ryssland, och det östliga partnerskapet. Andra frågor, som Nordstream 2, konflikten kring "Lidingöhuset", och den av ryska myndigheter extremistförklarade hemsidan Kavkaz Center, har under senare år nämnts i officiella sammanhang men förefaller mer sekundära. Rysslands ökade militära närvaro i östersjöregionen, en källa till nordisk-baltisk oro, förklaras officiellt vara ett svar på yttre hot. Enligt ryska ledares synsätt är agerandet defensivt, och en konsekvens av västmakternas, primärt Natos, ökade militära närvaro i ryskt "närområde». Sveriges ingående av ett så kallat värdlandsavtal med Nato i maj 2016 kritiserades av ryska politiker, även om Ryssland officiellt - fortsatt beskriver Sveriges "neutrala» (alliansfria) status som något positivt och önskvärt (Oldberg 2017). Påståendet att Ryssland bedriver påverkansoperationer mot Sverige har av Sergej Lavrov avfärdats som "propaganda", och från Moskvas sida betonas en beredvillighet att utveckla samarbete inom handel och andra områden (Yle 2017).

I en intervju för Dagens Nyheter 2016 identifierade Sergej Lavrov två frågor som försurat relationerna mellan Sverige och Ryssland: Sveriges kritik av annekteringen av Krim - enligt Lavrov en väntad rysk reaktion på den »beväpnade statskuppen i Kiev» - och att man från svenskt håll anslöt sig till EU:s handelssanktioner. Denna överdrivna kritik av den ryska utrikespolitiken, argumenterade utrikesministern, var kontraproduktiv, och det gällde att nu "stänga fönstret för dem som alstrar russofobi.» Ifall Sverige går med i Nato, förtydligade Lavrov vidare, "kommer vi [Ryssland] naturligtvis att vid våra nordliga gränser vidta nödvändiga militärtekniska åtgärder, eftersom det på andra sidan gränsen finns ett militärpolitiskt block som betraktar Ryssland som ett hot» (Dagens Nyheter 2016c). Liknande formuleringar återkom i en intervju med Vladimir Putin 2017, som konstaterade att "om Sverige går med i Nato kommer det självklart att ha en negativ effekt på våra bilaterala relationer. För oss betyder det att Nato expanderar mot våra gränser, även från svenskt territorium...» (Svenska Dagbladet 2017b).

Den svenska regeringen kom att tolka Vladimir Putins formulering som ett implicit hot, vilket den är såtillvida att Ryssland är en Sverige överlägsen militärmakt, men var i själva verket främst ett uttryck för den kontinuitet som utmärker 
Rysslands säkerhetsstrategiska förhållningssätt till den vidare östersjöregionen sedan kalla kriget. "I Sovjetunionen sätter vi stort värde på Sveriges neutralitetspolitik», stod det att läsa i den svenska upplagan av Leonid Brezjnevs memoarer 1978, "vilken är en av de viktiga faktorer som bidrar till att upprätthålla fred och säkerhet i Nordeuropa och spelar en positiv roll på den internationella arenan» (Brezjnev 1978: 14). Uppfattningen av Sverige som ett i säkerhetspolitiken "neutralt» land har varit en sedan kalla kriget återkommande rysk uppfattning, obeaktat svenskt EU-medlemskap sedan 1994 - möjligtvis som ett förenklat uttryck för Sveriges icke-medlemskap i Nato.

\section{Sammanfattande kommentarer}

En offentlig utredning på temat de svensk-sovjetiska relationerna under kalla kriget kunde 2002 konstatera att de "svensk-sovjetiska respektive svensk-ryska relationerna... alltid varit problemfyllda, och pendlat mellan kyla och, om inte värme så i vart fall någon form av normalitet.» (SOU 2002:132) Avslöjandet av spionen Stig Wennerström 1963 ledde till ett avbrott i kontakterna mellan Sverige och Sovjetunionen; den sovjetiska inmarschen i Tjeckoslovakien 1968 ledde till ytterligare en nedkylning $\mathrm{i}$ förbindelserna, men följdes efter en period om några år av en normalisering på 1970-talet; den sovjetiska Afghanistaninterventionen 1979, och det skärpta säkerhetsläget kring Östersjön på 1980-talet, inledde i sin tur ytterligare en ny fas av kyla, som kom att förbytas först med Michail Gorbatjovs glasnost, Olof Palmes initiativ till dialog med Moskva, och demokratiseringen under 1990-talet. Under denna tidsperiod kom därtill såväl Sverige som Ryssland att ansluta sig till en rad internationella samarbetsavtal, organisationer och konventioner.

Med Georgienkriget 2008 och Krimannekteringen 2014 kom de svensk-ryska relationerna att återigen försämras enligt välbekant mönster. Sverige och Ryssland fortsätter å ena sidan att ha en aktiv bilateral agenda inom områden som handel, investeringar och utbyte inom kultur och utbildning, om än på en lägre nivå jämfört med exempelvis 2000-talets första årtionde. Å andra sidan existerar ett antal frågor - som Ukrainakonflikten, EU:s östliga partnerskap, svenskt Natosamarbete och säkerhetsläget i Östersjön - där konkurrerande synsätt och anspråk mellan Sverige och Ryssland i dagsläget gör sig gällande. I ett historiskt perspektiv är denna växelverkan mellan två motstridiga tendenser ingenting avvikande, utan normen för de svensk-ryska relationerna. Sveriges insisterande på idealpolitik, med internationell rätt och mänskliga rättigheter som utrikespolitikens fundament, har under Vladimir Putins styre förblivit inkompatibel med en rysk utrikespolitik uttryckligen baserad på geopolitikens principer om "legitima intressesfärer». Under de senaste åren har Ryssland och Sverige bekräftat sina meningsskiljaktigheter, vilka sannolikt kommer att kvarstå givet att inga drastiska förändringar i de nuvarande politiska förhållandena mellan Ryssland och västmakterna äger rum. 


\section{Referenser}

Aftonbladet (2017) "Huset en 'allvarlig belastning' för rysk-svenska relationerna». 21 februari. Tillgänglig på http://www.aftonbladet.se/nyheter/a/8aJGW/huset-en-allvarlig-belastning-for-rysk-svenska-relationerna. Läst 21 augusti 2017.

Attman, Artur (1944) Den ryska marknaden i 1500-talets baltiska politik, 1558-1595. Lund: AB PH Lindstedts Akademibokhandel.

Berner, Örjan (1985) Sovjet och Norden, samarbete, säkerhet och konflikter under femtio år. Stockholm: Bonnier fakta.

Bildt, Carl (2009) "Samarbete med öst måste öka». Svenska Dagbladet 18. februari. Tillgänglig på https://www. svd.se/samarbete-med-ost-maste-oka. Läst 21 augusti 2017.

Brezjnev, Leonid (1978) Brezjnev: Sidor ur hans liv. Malmö: Corona.

Bring, Ove (2008) Neutralitetens uppgång och fall - eller den gemensamma säkerhetens historia. Stockholm: Atlantis.

Chrispinsson, John (2011) Den glömda historien: Om svenska öden och äventyr i öster under tusen år. Stockholm: Norstedts.

Dagens Nyheter (2006) "Rysk gas kan dras till Sverige». 14 november. Tillgänglig på http://www.dn.se/arkiv/ sverige/rysk-gas-kan-dras-till-sverige/. Läst 21 augusti 2017. Läst 21 augusti 2017.

Dagens Nyheter (2015a) "Ryska örlogsfartyg stör kabelläggning till Sverige». 2 maj. Tillgänglig på http://www. dn.se/nyheter/varlden/ryska-orlogsfartyg-stor-kabellaggning-till-sverige/. Läst 21 augusti 2017.

Dagens Nyheter (2015b) »Allt fler svenskar rädda för Ryssland». 23. juni. Tillgänglig på http://www.dn.se/nyheter/ sverige/allt-fler-svenskar-radda-for-ryssland/. Läst 21 augusti 2017.

Dagens Nyheter (2016a) "Ryska ambassadören: Sämre svensk-ryska relationer än under u-båtsjakten på 1980talet». 1 november. Tillgänglig på http://www.dn.se/nyheter/sverige/ryska-ambassadoren-samre-svenskryska-relationer-an-under-u-batsjakten-pa-1980-talet/. Läst 21 augusti 2017.

Dagens Nyheter (2016b) "Säpo varnar för ryskt psykologiskt krig - tiotal agenter på svensk mark». 17 mars. Tillgänglig på http://www.dn.se/nyheter/sverige/sapo-varnar-for-ryskt-psykologiskt-krig-tiotal-agenter-pa-svensk-mark/. Läst 21 augusti 2017.

Dagens Nyheter (2016c) "Om Sverige går med i Nato kommer vi att vidta nödvändiga åtgärder». 28 april. Tillgänglig på http://fokus.dn.se/lavrov/. Läst 21 augusti 2017.

Daucé, Françoise (2015) "The Duality of Coercion in Russia: Cracking Down on 'Foreign Agents'». Demokratizatsiya: The fournal of Post-Soviet Democratization 23 (1): 57-75.

Embassy of the Russian Federation to the United Kingdom of Great Britain and Northern Ireland (2014) "Comment by the Russian Ministry of Foreign Affairs regarding the situation involving the building of the Russian Trade Representation in Sweden». Tillgänglig på https://www.rusemb.org.uk/fnapr/4440. Läst 21 augusti 2017.

Expressen (2014) »Avlyssning mot SVT i Moskva - Säpo utreder». 15 oktober. Tillgänglig på http://www.expressen.se/nyheter/avlyssning-mot-svt-i-moskva---sapo-utreder/. Läst 21 augusti 2017.

Expressen (2015) „Ryska ambassaden står fast vid kritiken». 4 juli. Tillgänglig på http://www.expressen.se/nyheter/ryska-ambassaden-star-fast-vid-kritiken/. Läst 21 augusti 2017.

Flikke, Geir (2015) »Resurgent Authoritarianism: The Case of Russia's New NGO Legislation». Post-Soviet Affairs 32 (1): 103-131.

Fox, Anette Baker (1959) The Power of Small States: Diplomacy in World War II. Chicago, IL: University of Chicago Press.

Guriev, Sergei (2013) „Russia's New Stagnation». Project Syndicate. 14 november. Tillgänglig på https://www. project-syndicate.org/commentary/sergei-guriev-examines-the-implications-of-the-russian-government-s-downbeat-economic-forecast?barrier=accessreg. Läst 21 augusti 2017.

Handel, Michael (1981) Weak States in the International System. London: Frank Cass.

Hildebrand, K.-G. (1958) "Foreign Markets for Swedish Iron in the 18th Century». Scandinavian Economic History Review 6 (1): 3-52.

Hugemark, Bo (2011) Till bröders hjälp: Med sikte på en svensk solidarisk strategi. Stockholm: Kungl Krigsvetenskapsakademien 2011.

Komsomolskaja Pravda (2012) "'Sjvedskaja semja' rossijskoj oppozitsii». 21 maj. Tillgänglig på https://www.kompravda.eu/daily/25885.5/2847419/. Läst 21 augusti 2017.

Kragh, Martin (2014) "Patterns of Swedish-Russian Trade and Investments (1840s-1920s)» i Vadim Azbel et al. (red.) Swedish Business History in Russia, 1850-1917. Bromma: Centrum för näringslivshistoria (5-24).

Labs, Eric J. (1992) „Do Weak States Bandwagon»? Security Studies 1 (3): 383-416. 
Lagerqvist, Lars med flera (2004) Ryska statsbesök $i$ Sverige och mindre officiella visiter samt några svenska besök $i$ Ryssland. Stockholm: Kungliga myntkabinettet.

Lénart, Mats (2008) "Den krokiga vägen till Mosfilmovskaja». Tillgänglig på http://www.sfv.se/globalassets/kulturvarden/2008_03/s16-den_krokiga_vagen_till_mosfilmovskaja.pdf. Läst 21 augusti 2017.

MID (2008) "Russian MFA Information and Press Department Commentary in Connection with Sweden's Refusal to Extradite Aslan Adayev to Russia». Tillgänglig på http://www.mid.ru/en/foreign_policy/news/-/ asset_publisher/cKNonkJE02Bw/content/id/331539?p_p_id=101_INSTANCE_cKNonkJE02Bw\&_101_ INSTANCE_cKNonkJE02Bw_languageId=ru_RU. Läst 21 augusti 2017.

Oldberg, Ingmar (2017) "Kylig dialog mellan Ryssland och Sverige». Utrikesmagasinet 24 februari. Tillgänglig på http://www.utrikesmagasinet.se/analyser/2017/februari/kylig-dialog-mellan-ryssland-och-sverige/. Läst 21 augusti 2017.

Petersson, Bo (1994) Med Moskvas ögon. Smedjebacken: Bokförlaget Arena.

Pop, Valenita (2009) "EU expanding its 'sphere of influence' Russia says» EUobserver 21 mars. Tillgänglig på https:/euobserver.com/foreign/27827. Läst 21 augusti 2017.

Pravda (1976) "Sovmestnoe sovetsko-sjvedskoe kommiunike o visite v SSSR premer-ministra Sjvetsii». 10 april. Tillgänglig på http://istmat.info/node/22445. Läst 21 augusti 2017.

Regeringens deklaration (2009) »Regeringens deklaration vid 2009 års utrikespolitiska debatt i Riksdagen onsdagen den 18 februari 2009». Tillgänglig på http://www.regeringen.se/49b754/contentassets/9ccfe2b6d8ef4a0b8c477ce70b96d0a8/utrikesdeklarationen-2009. Läst 21 augusti 2017.

Regeringens deklaration (2010) »Regeringens deklaration vid 2010 års utrikespolitiska debatt i Riksdagen onsdagen den 17 februari 2010». Tillgänglig på www.regeringen.se/49b754/contentassets/271b66c5df54458ca8c00f01c5a4ab23/utrikesdeklarationen-2010. Läst 21 augusti 2017.

Regeringens deklaration (2014) »Regeringens deklaration vid 2014 års utrikespolitiska debatt i Riksdagen onsdagen den 19 februari 2014». Tillgänglig på http://www.regeringen.se/49b753/contentassets/37a11b11aa6c488abfc789b30402910a/utrikesdeklarationen-2014. Läst 21 augusti 2017.

Regeringens deklaration (2016) "Regeringens deklaration vid 2016 års utrikespolitiska debatt i riksdagen onsdagen den 24 februari 2016». Tillgänglig på http://www.regeringen.se/492b29/contentassets/5fe74c3cbdd34cab970d741362cdb133/utrikesdeklarationen-2016. Läst 21 augusti 2017.

Regeringens deklaration (2017) "Regeringens deklaration vid 2017 års utrikespolitiska debatt i riksdagen onsdagen den 15 februari 2017». Tillgänglig på http://www.regeringen.se/49192e/contentassets/b7cf8b05ddad4781883354c1c9bb2481/utrikesdeklarationen-2017-svenska.pdf. Läst 21 augusti 2017.

Regeringen (2016) »Med anledning av attacken mot journalister och människorättsaktivister i ryska Ingusjien». Tillgänglig på www.regeringen.se/uttalanden/2016/03/med-anledning-av-attacken-mot-journalister-och-manniskorattsaktivister-i-ryska-ingusjien. Läst 21 augusti 2017.

Ringsmose, Jens (2009) "Paying for Protection: Denmark's Military Expenditure during the Cold War». Cooperation and Conflict 44 (1): 73-97.

SOU 2002:108 (2002) Fred och säkerhet: svensk säkerhetspolitik 1969-1989: slutbetänkande. Stockholm: Fritzes offentliga publikationer. Tillgänglig på http://www.regeringen.se/49c824/contentassets/996575b3f6004b8491c2911257c6ed0c/kapitel-3-och-4. Läst 21 augusti 2017.

Svenska Dagbladet (2007a) "Rysk-svensk militärövning inledd». 12 december. Tillgänglig på www.svd.se/rysk-svensk-militarovning-inledd. Läst 21 augusti 2017.

Svenska Dagbladet (2007b) "Nord Stream storsatsar på Gotland». 27 november. Tillgänglig på https://www.svd. se/nord-stream-storsatsar-pa-gotland. Läst 21 augusti 2017.

Svenska Dagbladet (2013a) "Greenpeace trotsar Ryssland i Arktis». 24 augusti. Tillgänglig på https://www.svd. se/greenpeace-trotsar-ryssland-i-arktis. Läst 21 augusti 2017.

Svenska Dagbladet (2013b) "Svenska biståndet som går till Putins kärnkraft». 17 augusti. Tillgänglig på https:// www.svd.se/svenska-bistandet-som-gar-till-putins-karnkraft. Läst 21 augusti 2017.

Svenska Dagbladet (2013c) "Ryskt flyg övade anfall mot Sverige». 22 april. Tillgänglig på https://www.svd.se/ ryskt-flyg-ovade-anfall-mot-sverige. Läst 21 augusti 2017.

Svenska Dagbladet (2014) "Rysk ambassadör tog emot protester». 15 december. Tillgänglig på https://www.svd. se/rysk-ambassador-tog-emot-protester. Läst 21 augusti 2017.

Svenska Dagbladet (2017a) "Brev till Lavrov: utred hbtq-förföljelser». 4 maj. Tillgänglig på https://www.svd.se/ lavrov-uppmanas-utreda-hbtq-forfoljelser. Läst 21 augusti 2017.

Svenska Dagbladet (2017b) "Wallström: Putin ska avstå från att hota oss». 1 juni. Tillgänglig på https://www.svd. se/putin-inga-hackare-kan-paverka-val. Läst 21 augusti 2017. 


\section{MARTIN KRAGH}

Sveriges Radio (2007) "Skarp protest från UD till Ryssland». 20 maj. Tillgänglig på http://sverigesradio.se/sida/ artikel.aspx?programid=83\&artikel=1344198. Läst 21 augusti 2017.

Sveriges Radio (2008) "Bildt får kritik för Rysslandsuttalande». 2 september. Tillgänglig på http://sverigesradio. se/sida/artikel.aspx?programid=83\&artikel=2288408. Läst 21 augusti 2017.

Sveriges Radio (2015) "Nordiska ministerrådet klassas som utländsk agent». 24 januari. Tillgänglig på http:// sverigesradio.se/sida/artikel.aspx?programid $=83 \&$ artikel $=6076401$. Läst 21 augusti 2017.

SVT Nyheter (2015) "Så har svenska militären frusit kontakten med Ryssland». 6 maj. Tillgänglig på https:// www.svt.se/nyheter/inrikes/frysta-relationer. Läst 21 augusti.

Tsygankov, Andrei (2015) "Vladimir Putin's Last Stand: The Sources of Russia's Ukraine Policy». Post-Soviet Affairs 31 (4): 279-303.

Uggla, Martin (2011) "Rysk demokrati inte längre lika viktig». Östgruppen för demokrati och mänskliga rättigheter november. Tillgänglig på http://www.ostgruppen.se/wp-content/uploads/2011/03/Rysk-demokrati-inte-1\%C3\%A4ngre-lika-viktig.pdf. Läst 2 augusti 2017.

Veckans Affärer (2014) „Svenska säkerhetsnätet är i ryska händer». 23 april. Tillgänglig på https://www.va.se/ nyheter/2014/04/23/svenska-sakerhetsnatet-ar-i-ryska-hander/. Läst 21 augusti 2017.

Västkusten (1987) "Nya avslöjanden om avlyssning på Sveriges ambassad i Moskva». 12 mars. Tillgänglig på https://cdnc.ucr.edu/cgi-bin/cdnc?a=d\&d=VEST19870312.2.5. Läst 21 augusti 2017.

Vice, Margaret (2017) »Publics Worldwide Unfavorable Toward Putin, Russia. But few see Russian power and influence as a major threat». Pew Research Center 16. augusti. Tillgänglig på http://www.pewglobal. org/2017/08/16/publics-worldwide-unfavorable-toward-putin-russia/. Läst 21 augusti 2017.

Wahlbäck, Krister (1986) The Roots of Swedish Neutrality. Stockholm: Svenska Institutet.

Wallensteen, Ivar (1953) „Återblick på 1946 års svensk-ryska kreditavtal». Svensk Tidskrift 31 december. Tillgänglig på http://www.svensktidskrift.se/aterblick-pa-1946-ars-svensk-ryska-kreditavtal/. Läst 21 augusti 2017.

Yle (2017) "Töväder i relationen mellan Sverige och Ryssland? ». 22 februari. Tillgänglig på https://svenska.yle. fi/artikel/2017/02/21/tovader-i-relationen-mellan-sverige-och-ryssland. Läst 21 augusti 2017. 